\title{
BIOEDUSCIENCE
}

ISSN: 2614-1558

https://journal.uhamka.ac.id/index.php/bioeduscience

\section{The Opportunity of Spent Bleaching Earth (Bentonite) and Silica Solubilizing Bacteria as Silica Source for Induction of Secondary Metabolites Production in Plants}

\author{
Cico Jhon Karunia Simamora ${ }^{1}$, Ellia Septiarahma Rumambi ${ }^{1}$, Tika Widya Pratiwi ${ }^{1}$, Ajeng Maula Ningrum ${ }^{1}$, Taris \\ Zharfan Mias Embau²
}

${ }^{1}$ Agroteknologi, Universitas Tanjungpura, Jl. Prof. Dr. H. Hadari Nawawi, Pontianak, Indonesia 78124

${ }^{2}$ Teknologi Pangan, Universitas Tanjungpura, Jl. Prof. Dr. H. Hadari Nawawi, Pontianak, Indonesia 78124

*Correspondent Email: csomamora@faperta.untan.ac.id

Check for updates

\section{ARTICLE INFO}

\section{Article history}

Received: 29 Apr 2021

Accepted: 23 Jun 2021

Published: 31 Aug 2021

\section{Keywords:}

Secondary metabolite;

Silicate minerals;

Silica;

Silicate solubilizing

bacteria;

\section{A B S T R A C T}

Background: CPO refining, which produces solid waste in the form of spent bleaching earth (SBE) in large quantities, can pollute the environment. SBE from the type of bentonite contains large amounts of silica to be an alternative source of silica besides silica minerals. Silica plays a vital role in increasing plant resistance and bioactive plant compound products. Applying $\mathrm{Si}$ in plants can increase secondary metabolites such as phenolic and antifungal compounds in response to disease pathogens. However, the low solubility of silica makes silica not sufficiently available to plants. Methods: The use of microorganisms as silica solubilizing bacteria helps increase the solubility of silica in the soil. Bacteria dissolve silica by removing organic acids and producing indole acetic acid (AAI), which stimulates root hairs. Results: This review presents the results of a study on the utilization of silica-rich SBE waste as a source of available silica to plants. Conclusions: With the help of silica solubilizing bacteria, plant growth and resistance increase plant secondary metabolite compounds.

Peluang Sampah Bleaching Earth (Bentonite) dan Bakteri Pelarut Silika Sebagai Sumber Silika untuk Induksi Produksi Metabolit Sekunder Pada Tanaman

\section{A B S T R A K}

\section{Kata kunci:}

Bakteri pelarut silika;

Metabolit sekunder;

Mineral silika;

Silika;
Background: Penyulingan CPO yang menghasilkan limbah padat berupa spent bleacing earth (SBE) dalam jumlah yang banyak dapat mencemari lingkungan. SBE dari jenis bentonit mengandung silika dalam jumlah yang banyak, sehingga dapat menjadi sumber silika alternatif selain mineral silika. Silika berperan cukup penting dalam meningkatkan ketahanan tanaman dan produk senyawa bioaktif tanaman. Aplikasi Si pada tanaman dapat meningkatkan metabolit sekunder seperti senyawa fenolik dan anti jamur sebagai respon terhadap patogen penyakit. Namun, karena kelarutan silika yang rendah membuat silika tidak cukup tersedia bagi tanaman. Metode: Penggunaan mikroorganisme sebagai bakteri pelarut silika membantu meningkatkan kelarutan silika di dalam tanah. Bakteri melarutkan silika dengan mengeluarkan asam organik dan memproduksi asam indol asetat (AAI) yang dapat merangsang rambut-rambut akar. Hasil: Review ini menyajikan hasil studi tentang pemanfaatan limbah SBE yang kaya silika sebagai sumber silika tersedia bagi tanaman. Kesimpulan: dengan bantuan bakteri pelarut silika guna meningkatkan pertumbuhan dan ketahanan tanaman, serta meningkatkan senyawa metabolit sekunder tanaman. Kata kunci: Silika; Bakteri pelarut silika; Metabolit sekunder; Mineral silika

(C) 2021 by authors. License BIOEDUSCIENCE, UHAMKA, Jakarta. This article is open access distributed under the terms and conditions of a Creative Commons Attribution (CC-BY) license.

\section{Introduction}

One of the essential nutrients for plants is silica (Si), known as the beneficial element for rice plants (Epstein, 1999). Si's function in plants is to aid cell walls, prevent pests and pathogens, reduce water loss by evapotranspiration, and reduce heavy metals' toxicity and elements essential for normal development in some species (Savant et al., 1999). The availability of silica in the soil is a need for plants to deal with the growth period. Silica administration can also increase phosphorus (P) availability and reduce the activity of $\mathrm{Al}, \mathrm{Fe}$, and $\mathrm{Mn}$ (Yukamgo \& Yawono, 2007).

Lack of nutrients $\mathrm{Si}$ can reduce the optimum productivity of plants because silica has an essential role in increasing plant resistance. The beneficial effects of the si are usually clearly indicated when the plant is under stress. 
Silica in nature is very abundant sourced from the minerals quartz, feldspar, and bentonite. Empty bunches of palm oil are also a reasonably abundant silica raw material (Santi, 2016). In addition, CPO waste that is spent bleaching Earth (SBE) also contains much silica to be an alternative source of silica for plants. SBE waste is available exceedingly abundantly in Indonesia because it is associated with the increasing production of palm oil. This will trigger a buildup of SBE waste if it is not utilized optimally and can be bad for the environment.

Its availability for plants does not follow the abundance of silica sources in the soil. This is because silica is contained in the soil in elements that plants cannot absorb. The availability of nutrients for plants is influenced by the soil's ability to supply nutrients and the ability of plants to absorb the nutrients available. The addition of silica solvent microorganisms contributes to aiding the solubility of silica in the soil so that plants can absorb silica. Many microorganisms can release silica bonds from silica minerals, including Burkholderia, Bacillus, Pseudomonas, and Penicillium. Bacteria can dissolve silica by producing organic acids that stimulate plant growth and secondary metabolism (Santi, 2016; Vasanthi et al., 2018; Kang et al., 2017).

Based on the description that underlies the need for a literature review of the use of SBE as a potential silica source through the application of silica solvent bacteria to meet the needs of plant silica to increase plant growth and resistance and increase secondary metabolite compounds in plants.

\section{Methods}

The method used in this narrative review is reviewing scientific articles published in national and international journals. Used as many as 38 scientific articles for the source of narrative review writing literature with the title Bleaching Earth Waste Opportunity (Bentonite) as a Source of Silica in the Induction of Secondary Metabolites of Plants. Details of the use of scientific articles consist of 3 articles in review manuscripts, 34 scientific articles (research articles), and one book. The theme is raised from proposals that have been considered worthy of research. Citation writing using reference management software such as Mendeley with report following APA rules

\section{Results}

\section{Silica and Plant Metabolism}

Silica ( $\mathrm{Si}$ ) is a building element for plants that are a beneficial element i.e. increasing plant resistance to pest and disease attacks, repairing abiotic acid, and increasing plant growth (Marschner, 1995). Silica can increase plant resistance to disease and pest attacks, particularly in the graminae family. Specifically, silica can affect epidermal cells, thicken cell walls, and reduce transpiration so pest infestations and disease infections will decrease (Gardner \&Barber, 1981). Silica is absorbed by plants in monosilicate acid (H4SiO4) (Jones \& Handreck, 1967). In soil, the element $\mathrm{Si}$ is primarily present as $\mathrm{SiO} 2$, about $50-70 \%$ of the mass of the soil, and in various forms of aluminosilicate (Sommer et al., 2006). Although si is abundant in the soil, most of these elements are not available to plants due to the low solubility of the si compounds in the soil (Peera et al., 2016).

Silica plays a role in plant tolerance to abiotic stress by increasing the activity of enzymes and antioxidant compounds and helping to increase the efficiency of osmoregulatory by affecting water content levels, decreasing water loss due to transpiration, regulating nutrient adequacy, and limiting the absorption of toxic ions (Sacała, 2009). Silica also plays a role in lowering the rate of pest and disease attacks through two mechanisms: mechanical and physiological barriers in increasing resistance to pests and diseases (Abed-Ashtiani et al., 2012). Silica layers with a thickness of $2.5 \mu \mathrm{m}$ under the cuticle produce a double layer of cuticle silica that can inhibit or delay pest penetration (Rodrigues \&Datnoff, 2005). Silica fertilization is vital in rice cultivation because the silica content available in the soil continues to decrease. Silica can affect the concentration of plant defence metabolites and increased activity of defence enzymes such as chitinase, $\beta$-1,3-glucanase, phenylalanine ammonialyase, and polyphenol oxidase) that function in fighting biotrophic and hemibiotrophic pathogens) (Rémus et al., 2005).

\section{Correlation of Silica Availability and Increase in Secondary Metabolite Compounds}

Silica is one of the essential nutrients for plants in the tropics that plants in the form of $\mathrm{Si}$ absorb $(\mathrm{OH}) 4$ (Sahebi et al., 2015). Metabolic changes in plants are triggered by biochemical responses that occur (Bhat et al., 2019).

Silica is polymerized within epidermal cells, strengthening plant cell membranes, maintaining water potential, and preventing electrolyte leakage (Agarie et al. 1998). Si application in some plants may stimulate the accumulation of phenolic and fungi toxic compounds in roses (Shetty R, 2011), fungi toxic compounds in cucumbers (Fawe et al., 1998), and antifungal compounds in potato plants (Li et al., 2009), in response to starchy dew pathogens. The binding of silicate acid to phenolic components and cell wall carbohydrates supports the formation of various phenol-carbohydrate complexes.

Si application can increase si deposits and decrease the content of ferulic acid and p-kumari acid in rice (Goto et al., 2003). Si's application in plants allows plants to produce secondary metabolites optimally. Secondary metabolite compounds in plants and practical inhibiting disease attacks in plants also have other functions such as 
antioxidants and anticancer found in certain plants. Alternative silica fertilizers for plants can be used from SBE waste.

\section{Spent Bleaching Earth (SBE) Bentonite as a Source of Natural Silica}

Bentonite is a substance that resembles montmorillonite crystals, and its structure has a dioctahedral shape; trivalent cations occupy two-thirds of octahedral. Bentonite is named in Spent Bleaching Earth or is commonly used as a built-in colour absorbent in CPO. It is estimated that more than 60 million tons of SBE are used worldwide (Kheang et al., 2006). Spent Bleaching earth (SBE) consists of several types, including bentonite, lynit, and activated charcoal (Ashari et al., 2017). Bentonite is one type of clay derived from weathering and hydrothermal reactions. Its availability is relatively abundant in Indonesia and spread in several regions, such as Java, Sumatra, Kalimantan, and Sulawesi. Bentonite also contains montmorilonite (Nugrahani \& Ismiyati, 2014). Montmorillonite is a group of clay minerals that form microscopic crystals. The water content of montmorillonite varies so that when it purifies, the water will expand to several times the initial volume.

The use of SBE that continues to increase affects the accumulation of SBE waste, so there needs to be sBE waste treatment. One of them is an alternative as a source of silica fertilizer. SBE made from bentonite clay contains many elements $\mathrm{SiO} 2$ and $\mathrm{Al} 2 \mathrm{O3}$; this element also affects the process of palm oil.

Silica is the most considerable elemental content in bentonite; the structure of montmorillonite sheets is arranged by two layers of 2-tetrahedral containing silica and one octahedral layer containing alumina (Loveland, 1999). This silica element can later be used in fertilization in the soil, but because of the strong bonding of the element in bentonite, the breakdown of the structure needs to be done. This source of silica in bentonite can be an alternative to silica for plants. One way is to use silica solvent bacteria to release elemental bonds in bentonite, thus allowing the bonding of elements in bentonite regardless of the si element.

\section{Positive Correlation of Silica Solvent Bacteria and Plant Growth Activity}

Although silica is the second most nutrient in the earth's crust and soil, it does not make it an essential nutrient for high-level plants (Epstein, 1999). This is because some of the silica in the soil is not available to plants. After all, Si's solubility in the soil is relatively low (Santi \& Goenadi, 2017). In addition, the decline of Si in the soil can occur in intensive cultivation practices and continuous sustainable monoculture cultivation. As a result, these lands generally have low available Si (Meena et al.,
2014). To increase silica solubility in the soil, silica solvent bacteria play an essential role in dissolving silica into being available. Silica solvent bacteria are also recommended as biological fertilizers to dissolve silica (Vasanthi et al. 2018). Some of the microbes studied were able to dissolve silica from natural minerals, namely Bacillus cladolytycus, $B$. mucilaginosus, Pseudomonas sp, Penicillium sp (Santi, 2016), Bacillus flexus, B. megaterium, Pseudomonas fluorescens (Vasanthi et al., 2018), and Burkholderia eburnean (Kang et al., 2017).

Silica solvent bacteria are used as bio-fertilizers and have been shown to promote growth, suppress pest and disease attacks, and increase crop yields. Research shows that silica can increase the persistence of biological agents to survive in the environment and effectively prevent pest attacks and diseases that occur in peatlands (Simamora et al., 2013). After inoculation in rice plants, Bacillus species isolated from soil containing granite granules can increase biomass and grain yields (Meena et al., 2014). The inoculation of silica solvent bacteria in some natural silicates not only dissolves silica but simultaneously releases phosphorus and potassium (Meena et al., 2014). In addition, silica solvent bacteria are also confirmed to increase the solubility of elements $\mathrm{Ca}$ and $\mathrm{Mg}$ as secondary nutrients (Santi \& Goenadi, 2017).

Burkholderia eburnean isolates combined with unused almond silica significantly promote rice plant growth such as bud length, root length, fresh weight of shoots, fresh weight of roots, and chlorophyll content (Kang et al., 2017). The availability of Si is increased due to the application of B. eburnean increases deposition in the leaves and surface area of the leaves, thus helping the absorption of sunlight that can improve the process of photosynthesis (Gong et al., 2005).

\section{Silica and Silica Solvent Bacterial Formulations Linked to Metabolite Productivity Support}

Inoculation of silica solvent bacteria can release silica in the soil and remove Si from silica minerals (Meena et al., 2014). It is seen that the bacteria tested can dissolve silica. Inoculation tests of silica solvent bacteria strains with silica minerals (magnesium tricyclic and feldspar) showed that Bacillus mucilaginous and Pseudomonas are the best silica solvent bacteria, characterized by the formation of clear zones around bacterial growth (Vasanthi et al., 2018). Bacteria in the soil can dissolve unavailable silica such as quartz by removing organic acids and directly dissolve potassium rocks or silica chelate ions to bring potassium and silica into solution (Santi \&Goenadi, 2017).

Rhizobakteri isolates identified by Kang et al. (2017) as Burkholderia eburnean can dissolve silica and be associated with organic acid production, especially gluconic acid. Three selected strains of silica solvent bacteria from Santi and Goenadi's study (2017) produced high citric acid, 
acetic acid, and oxalic acid. Burkholderia cenocepacia strain has a high ability to produce acetic acid, while Aeromonas punctata strain can produce citric acid and oxalic acid (Santi \& Goenadi. 2017).

Table 1. Production of Organic Acids by Silica Solvent Bacteria

\begin{tabular}{|c|c|c|}
\hline Types of Bacteria & Organic Acids & References \\
\hline B. eburnean & Gluconic acid & $\begin{array}{c}\text { Kang et } \\
\text { al. (2017) }\end{array}$ \\
\hline B. сепосерасіа & Citric acid, acetate, oxalate & Santi \\
\hline A. punctata & Citric acid, acetate, oxalate & $\begin{array}{c}\text { dan Goenadi, } \\
\text { (2017) }\end{array}$ \\
\hline B. vietnamiensis & Citric acid, acetate, oxalate & \\
\hline B. flexus & $\begin{array}{l}\text { Malic acid, citrate, tartarate, } \\
\text { gluconics and oxalate }\end{array}$ & $\begin{array}{l}\text { Vasanthi et } \\
\text { al. (2018) }\end{array}$ \\
\hline B. mucilaginosus & $\begin{array}{l}\text { Acetic acid, hydroxy propionic, } \\
\text { phthalate, gluconic, oleic, } \\
\text { tartaric and citric acid }\end{array}$ & \\
\hline
\end{tabular}

In addition to organic acid production, silica solvent bacteria also release silica by producing extracellular polysaccharides (EPS) (Liu et al., 2006) and exopolysaccharides (Santi \&Goenadi., 2017). The B. eburnean isolate has been shown to produce acetic indol acid (AAI) that stimulates root hair initiation. It increases the number and size of primary and lateral roots (Kang et al., 2017). The utilization of silica in available form (bio-silica) for crops and plantations has the potential as a mediator to increase resistance to climate change, especially in prolonged dry conditions (Santi, 2016). Plant roots absorb silica as silicate acid. Once absorbed, silica moves quickly to the point of active growth, where silica combines with organic compounds to increase the strength of the cell wall, which contributes to the growth of more substantial plant parts (Kang et al., 2017).

\section{Conclusions}

The availability of silica in nature is relatively abundant, but silica's low solubility makes silica unavailable to plants. Low solubility is an essential factor in the unavailability of silica for plants, even though plants need silica as a beneficial element for most plants, especially the Gramineae group and other cultivated plants. One potential source of silica is silica-rich Spent Bleaching Earth (SBE) and accumulates a lot as a palm oil refining waste. The application of silica solvent bacteria has been known to play an essential role in providing silica to plants through enzymatic mechanisms, namely the production of organic acids and extracellular polysaccharides. The strategic application and identification of silica dissolution play an essential role in dissolving silica in the soil, i.e. with the combination of silica solvent bacteria applied to SBE. The potential dissolution of silica from SBE waste with silica solvent bacteria needs to be studied to see specific influences on crops' growth and systemic resistance. SBE waste production is increasing, and the abundant content of $\mathrm{Si}$ is potential as a silica-rich fertilizer that is beneficial for plants. The utilization of various groups of silica solvent bacteria is expected to dissolve Si in SBE. SBE, which is classified as waste B3, needs further research related to the content of Si and the harmful content before being used for si production.

\section{Giving Thanks}

The author would like to say a lot of thanks to the Ministry of Education and Culture of the Republic of Indonesia (Kemendikbud RI) as a grant grant grant in this research. Thank you also to our mentor Mr. Cico Jhon Karunia Simamora, S.P., M.Si who has helped us a lot in compiling and correcting the writing of this review. And thank you for the dedication of team members and all parties involved in writing this review.

\section{Declaration statement}

The authors reported no potential conflict of interest.

\section{References}

Abed-Ashtiani, F. et al. (2012) 'Effect of foliar and root application of silicon against rice blast fungus in MR219 rice variety', Plant Pathology Journal, 28(2), pp.

https://doi.org/10.5423/PPJ.2012.28.2.164. 164-171.

Agarie, S. et al (1998) 'Effects of Silicon on Tolerance to Water Deficit and Heat Stress in Rice Plants (Oryza sativa L.), Monitored by Electrolyte Leakage', Plant Production Science, 1, pp. 96-103. Available at: http://www.mendeley.com/research/geologyvolcanic-history-eruptive-style-yakedake-volcanogroup-central-japan/.

Ashari, M. L., Dermawan, D. and Sunarya, R. B. (2017) 'Pemanfaatan Limbah Padat Spent Bleaching Earth Pada PT . SMART Tbk . Surabaya Sebagai Pengganti Agregat Halus pada Campuran Beton', Seminar Master 2017 PPNS, 1509, pp. 123-128.

Bhat, J. A. et al. (2019) 'Role of silicon in mitigation of heavy metal stresses in crop plants', Plants, 8(3), pp. 1-20. https://doi.org/10.3390/plants8030071.

Enggarini, W. and Marwani, E. (2006) 'Pengaruh Cekaman Aluminium terhadap Kandungan Asam Organik dalam Kalus dan Pinak Tomat (Lycopersicon esculentum Mill.)', Jurnal AgroBiogen, 2(1), p. 24. https://doi.org/10.21082/jbio.v2n1.2006.p24-29.

Epstein, E. (1999) 'Silicon', Annu. Rev.Plant Physiol. Plant Mol. Biol., (50), pp. 641-664.

Fawe, A. et al. (1998) 'Silicon-mediated accumulation of flavonoid phytoalexins in cucumber', Phytopathology, 88(5), pp. 396-401. doi: 10.1094/PHYTO.1998.88.5.396.

Gardner and Barber (1981) 'Proteoid root morphology and function in Lupinus albus', Plant and soil, 147(1981), pp. 143-147. 
Goto, M. et al. (2003) 'Protective effect of silicon on phenolic biosynthesis and ultraviolet spectral stress in rice crop', Plant Science, 164(3), pp. 349-356. https://doi.org/10.1016/S0168-9452(02)00419-3.

Husnain (2009) 'Ketersediaan Silika (Si) Pada Tanah Sawah dan Metode Penetapan Si Tersedia di Dalam Tanah Serta Perbandingan Beberapa Metode Ekstraksinya', Prosiding Seminar dan Lokakarya Nasional Inovasi Sumberdaya, pp. 155-163.

Jones, L. H. P. and Handreck, K. A. (1967) 'Silica In Soils, Plants, and Animals', Advances in Agronomy, 19(C), pp. 107-149. https://doi.org/10.1016/S00652113(08)60734-8.

Kang, S. M. et al. (2017) 'Isolation and characterization of a novel silicate-solubilizing bacterial strain Burkholderia eburnea CS4-2 promotes japonica rice (Oryza sativa L. cv. Dongjin)', Soil Science and Plant Nutrition. Taylor \& Francis, 63(3), pp. 233-241. https://doi.org/10.1080/00380768.2017.1314829.

Kheang, L. S. et al. (2006) 'A Study of Residual Oils Recovered from Spent Bleaching Earth: Their Characteristics and Applications', American Journal of Applied Sciences, 3(10), pp. 2063-2067. doi: 10.3844/ajassp.2006.2063.2067.

Kurabachew, H. and Wydra, K. (2014) 'Induction of systemic resistance and defence-related enzymes after elicitation of resistance by rhizobacteria and silicon application against Ralstonia solanacearum in tomato (Solanum lycopersicum)', Crop Protection. Elsevier Ltd, 57, pp. 1-7. https://doi.org/10.1016/j.cropro.2013.10.021.

Li, Y. C. et al. (2009) 'Antifungal activity of sodium silicate on Fusarium Sulphureum and Its effect on dry rot of potato tubers', Journal of Food Science, 74(5). doi: 10.1111/j.1750-3841.2009.01154.x.

Liu, W. et al. (2006) 'Decomposition of silicate minerals by Bacillus mucilaginosus in liquid culture', Environmental Geochemistry and Health, 28(1-2), pp. 133-140. https://doi.org/ 10.1007/s10653-0059022-0.

Loveland, P. J. (1999) 'Clay Mineralogy at Rothamsted: 1934-1988', Clay Minerals, 34(1), pp. 165-183. https://doi.org/ 10.1180/claymin.1999.034.1.17.

Marschner, H. (1995) 'Mineral nutrition of higher plants, second edition', Field Crops Research, 46(1-3), pp. 184-185. 4290(96)84669-7.

Meena, V. D. et al. (2014) 'A case for silicon fertilization to improve crop yields in tropical soils', Proceedings of the National Academy of Sciences India Section B Biological Sciences, 84(3), pp. 505-518. https://doi.org/ 10.1007/s40011-013-0270-y.

Nathan, A. J. and Scobell, A. (2012) 'How China sees America', Foreign Affairs, 91(5), pp. 1689-1699. https://doi.org/ 10.1017/CB09781107415324.004.
Nugrahani, R. A. and Ismiyati (2014) 'Pemanfaatan Nanobentonit Sebagai Bahan Tambahan Pada Formula Grease, Kosmetik dan Nanokomposit', Seminar Nasional Sains dan Teknologi, (November), pp. 1-4.

Peera, S. K. P. G., Balasubramaniam, P. and Mahendran, P. P. (2016) 'Effect of silicate solubilizing bacteria and fly ash on silicon uptake and yield of rice under lowland ecosystem', Journal of Applied and Natural Science, 8(1), pp. 55-59. https://doi.org/ 10.31018/jans.v8i1.746.

Rémus-Borel, W., Menzies, J. G. and Bélanger, R. R. (2005) 'Silicon induces antifungal compounds in powdery mildew-infected wheat', Physiological and Molecular Plant Pathology, 66(3), pp. 108-115. doi: 10.1016/j.pmpp.2005.05.006.

Rodrigues, F. A. and Datnoff, L. E. (2005) 'Silicon and rice disease management', Fitopatologia Brasileira, $30(5)$, pp. 457-469. doi: 10.1590/s010041582005000500001 .

Rosmarkam dan Yuwono. 2002. Ilmu Kesuburan Tanah. Kanisius: Yogyakarta.

Ryan, at al. (2001), function and mechanism of oraganic anion exudation from plant roots. Annu. Rev. Plant Physiol. Plant Mol. Biol. 52: pp 527-60

Sacała, E. (2009) 'Role of silicon in plant resistance to water stress', Journal of Elementology, 14(3), pp. 619-630. doi: 10.5601/jelem.2009.14.3.20.

Sahebi, M. et al. (2015) 'Importance of silicon and mechanisms of biosilica formation in plants', BioMed Research International, $2015 . \quad$ doi: $10.1155 / 2015 / 396010$

Santi, L. P., 2016. Pemanfaatan Bio-Silika untuk Meningkatkan Produktivitas dan Ketahanan. Mataram, Pusat Penelitian Bioteknologi dan Bioindustri Indonesia

Santi, L. P. and Goenadi, D. H. (2017) 'Solubilization of silicate from quartz mineral by potential silicate solubilizing bacteria (Pelarutan silika asal mineral kuarsa oleh bakteri pelarut silika potensial )', EJournal Menara Perkebunan, 85(2), pp. 95-104. doi: 10.22302/iribb.jur.mp.v85i2.247.

Simamora, C. J. K., Ramadhan, T. R., Hendarti, I. 2013. Persistensi Cendawan Metarhizium anisopliae (Metsch) Pada Tanah Gambut Serta Tingkat Patogenistasnya Terhadap Larva Tenebrio molitor (Linn.) di Laboratorium. Jurnal Sains Mahasiswa Pertanian, (2), 1.

Shetty R, F. X. J. B. S. N. J. J. J. H. N. M., 2011. Perubahan yang Diinduksi Silikon pada Asam Fenolik Antijamur, Flavonoid, dan gen jalur fenilpropanoid Kunci selama Interaksi antara Mawar Miniatur dan Patogen Biotrofik Podosphaera pannosa. Fisiologi Tumbuhan, Volume 157, pp. 2194-2205. 
Sommer, M. et al. (2006) 'Silicon pools and fluxes in soils and landscapes - A review', Journal of Plant Nutrition and Soil Science, 169(3), pp. 310-329. doi: $10.1002 / j p l n .200521981$.

Vandevivere, P., Welch, S. A. and Ullman, W. J. (1994) 'MICROBIAL', pp. 241-251.

Vasanthi, N., Saleena, L. M. and Raj, S. A. (2018) 'Silica Solubilization Potential of Certain Bacterial Species in the Presence of Different Silicate Minerals', Silicon, 10(2), pp. 267-275. doi: 10.1007/s12633-016-94384.

Watanabe, T. and Osaki, M. (2002) 'Mechanisms of adaptation to high aluminum condition in native plant species growing in acid soils: A review', Communications in Soil Science and Plant Analysis, $33(7-8)$, pp. 1247-1260. doi: 10.1081/CSS120003885.

Yukamgo, E, dan N. W. Yuwono. 2007. Peran Silikon Sebagai Unsur Bermanfaat Pada Tanaman Tebu. Jurnal Ilmu Tanah dan Lingkungan, 7(2), pp. 103-116. 